\title{
Assessing the Influence of Foreign Direct Investment on the Economic Growth of United States
}

\author{
Adeola A. Adeniyi \\ International Business Department, Southern New Hampshire University, 2500 North River Road, Manchester, \\ NH 03106
}

\begin{abstract}
Researchers have found mixed empirical results on the significance of Foreign Direct Investment (FDI) on countries around the world. Foreign direct investment has been a major driver in the economic growth of both developed and developing economies. This study examines the influence of FDI on economic growth in a single developed country, the United States. Even though the United States has been the largest attractive nation for foreign direct investment among developed economies, there is need to research on how FDI has contributed to its development. Therefore, this paper uses multiple linear regression model and its estimation using ordinary least squares (OLS) to study the impact of FDI on economic growth in the United States. Analysis of secondary data from the Bureau of Economic Analysis (BEA), and Bureau of Labor Statistic (BLS) for the year 2000 to 2018 revealed that foreign direct investment has a positive influence on the economic growth of United States. Therefore, the study recommends that the government of United States should continue to revamp investment and fiscal policies to attract new foreign investors through continuous investing in social infrastructures, improving the quality of their institutions and their governance.
\end{abstract}

Keywords: Gross Domestic Product (GDP), Foreign Direct Investment, Inflation Rate, Economic Growth.

DOI: $10.7176 / \mathrm{JESD} / 11-16-12$

Publication date:August $31^{\text {st }} 2020$

\subsection{Introduction}

The impact of Foreign Direct Investment on the economic growth of host countries has been a major point of discussion by economists since the 1980s (Attari et al., 2011). The Organization for Economic Co-operation and Development (2008) defines foreign direct investment as a key driver of international economic integration that can provide financial stability, promote economic development and enhance the wellbeing of societies. FDI has not only been the most stable and largest component of capital flows that has contributed to the impressive economic growth in a number of developing countries (Adams, 2009; Anwar \& Nguyen, 2010; El-Wassal, 2012) but there exists considerable evidence on the relationship between FDI and economic growth in developed countries (Arisoy, 2012).

The United States (U.S.) occupies a unique position in the global economy of the world as the largest investor and the largest recipient of foreign direct investment (Jackson, 2017). According to International Trade Administration (2020), United States maintained the lead in the world's foreign direct investments. The country remains an attractive FDI destination for a variety of reasons which includes its large consumer base, a productive workforce, a business environment that encourages innovation and its legal protections. The nation's historical strengths, openness to foreign investment longer than most countries and large investment inflows from international investors make the nation the best country for their FDI level among all countries of the world (Susilo, 2018).

The U.S. foreign direct investment policy has been founded on the concept that the net benefits of FDI are positive and benefit both the United States and the foreign investors. The United Nations Conference on Trade and Development, UNCTAD (2008) reports that FDI inflows have the potential to create employment, increase productivity, transfer skills and technology, boost exports and continue long-term economic growth and development. Chappelow (2019) states that increases in capital goods, labor force, technology, and human capital lead to economic development. Foreign firms therefore make investments in the U.S. on a regular basis by establishing new operations, purchasing existing operations of another company, or providing additional capital to their existing U.S. operations (U.S. Department of Commerce, 2017).

The role of FDI as a critical factor in world economy has received increased attention in recent years leading to increased interest by both researchers and policy makers (Oladipo, 2007; Susilo, 2018). There have been mixed evidences of the growth effects of FDI from empirical literature. While there are empirical evidences that FDI generates economic growth (Mody \& Wang, 1997; Nair-Reichert \& Weinhold, 2001; Lensink \& Morrissey,2006), a number of studies still show a negative effect depending on the variables included in the study (Mohnen, 2001; Asheghian, 2004). Bhatt (2014) examined the impact of FDI on economic growth. The empirical results of the study confirmed strong evidence on the causal impact of FDI on growth for the countries under consideration. The same empirical results are supported by the studies of Tan \& Tang (2016) and Vogiatzoglou \& Thi, (2016). The study of Pegkas, (2015) also suggests that FDI stimulates economic growth in Eurozone countries. However, 
studies by Gillman \& Kejak (2005) and Fountas et al. (2006) found a negative impact of FDI on economic growth.

For a long time, FDI has been considered as one of the key driving forces of United States' economic growth. U.S. communities bid actively against each other for FDI (Figlio,1999). Foreign direct investments are highly sought after by many state and local governments that are struggling to create additional jobs in their localities (Jackson, 2017). But how does FDI influence the Gross Domestic Products (GDP) of the United States? This study seeks to analyze the relationship between the two variables for a period of eighteen years from year 2000 to year 2018. Secondary data from the Bureau of Economic Analysis (BEA), and Bureau of Labor Statistic were assessed using the multiple linear regression model with ordinary least square estimation and SPSS. The multiple regression identifies the relationship between the independent variables and the dependent variable. Variables used in the study are GDP as a measure of economic growth, gross inflows of FDI, and inflation rate. This study hypothesizes that foreign direct investment has a positive relationship on GDP in the United States.

It is important to understand the relationship between FDI and economic growth for the country. This will assist policy makers in dealing with the challenges of global markets. The output of the study will better inform them on the general implications for development strategy and proper management of foreign investment to stimulate domestic growth and innovation in the country.

The next section presents the literature review of the study, followed by the description of the model specification, the methodology of the study and the results of the statistical analysis. The paper concludes with a discussion of the results and findings, recommendations and suggestions for future research.

\subsection{Literature Review}

Data on global foreign direct investment (FDI) flows show that in recent years, despite increasing FDI inflows to developing countries, developed economies continue to be the largest recipients of foreign capital (Ntembe \& Sengupta, 2016). The world's economies have recognized the value of foreign investment, resulting in an increasingly competitive international environment for FDI flows. Foreign direct investment is an important source of growth in host countries (Blomstrom \& Kokko 1998; Li \& Liu, 2005). FDI is generally considered as a factor that enhances economic growth in host country as well as the solution to the economic problems of developing countries (Mencinger, 2003). It could play an important role in increasing the productivity of the host countries, hence sustaining economic development (Iacovoiu, 2015). The Organization for Economic Co-operation and development, OECD (1996) stated that FDI is a lasting interest by a resident entity in one economy (direct investor) in an entity resident in an economy other than that of the investor (direct investment enterprise). Similarly, the Bureau of Economic Analysis (BEA) defines foreign direct investment as an investment in which a resident of one country obtains a lasting interest in, and a degree of influence over the management of a business enterprise in another country.

Foreign direct investment is an essential component of the U.S. economy and it will continue to have a significant and positive influence on the nation (U.S. Dept. of Commerce, International Trade Administration, 2008). According to the International Trade Administration (2008), FDI is generally divided into the greenfield investment and the mergers and acquisitions. Greenfield investment is the creation of new enterprises and the development or expansion of production facilities. The Bureau of Economic Analysis (2019) describes a greenfield investment as a project where foreign investors establish a new business or expand an existing business on U.S. soil or on foreign soil. It is an avenue of creating employment for the economy where the greenfield investment is taking place. In the year 2018, greenfield investment expenditure to establish a new U.S. business or to expand an existing foreign-owned U.S. business was $\$ 9.1$ billion (BEA, 2019).

Every year, foreign companies and their U.S. subsidiaries announce plans for hundreds of new greenfield projects. The announcement or the opening of greenfield projects along with expansions in existing U.S. subsidiaries' operations by foreign-based companies generates enormous economic benefits for the American economy. These new ventures bring billions of investment dollars into the United States and create thousands of insourced American jobs.

Mergers and acquisitions (M\&A) involve the purchase of an existing enterprise. It is the buying and selling of existing capital. M\&A is more affected by geographic and cultural barriers and exhibits opportunistic behaviors as it is more sensitive to temporary shocks such as a currency crisis. M\&A is affected by destination factors such as financial development and institutional quality. Greenfield, on the other hand, is relatively more driven by factors such as origin comparative advantage and destination taxes.

Theories on investment studies underline the relationship between FDI and economic development. The empirical studies on FDI and growth derives from either neoclassical model of growth or endogenous growth models (Nair-Reichert \& Weinhold, 2001: 154). Neoclassical growth theory shows that FDI is plausibly an engine of growth because it enhances capital formation, employment, promotes new technologies, managerial skills and knowledge flows, and results in spillover effects (Hong, 2011: 772). FDI brings cutting edge technology and knowhow to their subsidiaries in a foreign country; it benefits the local economy via training local workers and the technology spillovers to domestic firms (Wu \& Burge, 2017). The FDI is a significant contributor to the 
competitiveness of the US high-tech sector. Select USA (2017) specified that "high-tech industries are important drivers of growth for the U.S. economy. These industries advance innovation, employ millions of highly skilled and highly educated workers, and thus further U.S. competitiveness in an increasingly globalized world. Rana \& Dowling, (1988) indicated that FDI was a growth enhancer through the human development spillover from the foreign investors. Considering that capital formation and technological improvement are the motor of economic growth, FDI is expected to promote host countries' economic growth (Wang, 2009).

Researchers around the world have found mixed empirical results on the relationship between FDI and economic growth of a country.

According to De Mello (1999), FDI accompanies more benefits than other investments since this kind of investment has a positive effect on productivity growth through technology transmission and managerial specialization as well as domestic investment. In his study, the contribution of FDI to economic growth is enhanced by its positive interaction with human capital, sound macroeconomic policies and institutional stability. The empirical results of the study by Bhatt (2014), Tan \& Tang (2016) and Vogiatzoglou \& Thi (2016) confirmed strong evidence on the causal impact of FDI on growth for the countries under consideration in their different studies. Lee \& Tacha (2004) stated that FDI plays an important role in improving the factors of production and accumulation of capital in the host country due to the competition it creates. The study of Pegkas (2015) further confirmed that FDI stimulates economic growth in Eurozone countries. In Ireland, Kim \& Bang (2008) found that FDI had a positive and statistically significant effect on growth in the short and long term. Studies by Ashegian (2004) and Roy \&Van der Berg (2006) concluded that FDI causes economic growth for the United States.

There are studies that found a negative impact on economic growth. In the study by Bende- Nabende et al. (2001) on four Asian countries, the impact of FDI is positive and significant in the Philippines and Thailand but negative in Taiwan and Japan, two countries which are more developed countries with a higher level of education. Chowdhury \& Mavrotas (2003) and Kasibhatla et al. (2008) found evidence that it is possible that it is not FDI that causes economic growth, but rather, the host country's economic growth attracts FDI. Chowdhury \& Mavrotas (2003) found positive effects for Malaysia and Thailand, but in Chile the evidence shows that it was the economic growth that led to increased FDI. Kasibhatla et al. (2008) analyzed five countries and only found positive effects for India. The United States consistently ranks at or near the top of most major indicators for an attractive business and investment climate (U.S. Department of Commerce, 2008). The long-standing policy of the United States is to support open investment and national treatment for foreign direct investment (Obama, 2011). Bearing in mind these theoretical and empirical research regarding FDI and economic development from different studies, this paper analyzes the relationship between FDI and economic development in the United States. It examines whether FDI generates a boost in economic growth in the country.

\subsection{Data and Methodology}

The secondary data used in this study was obtained from the Bureau of Economic Analysis and Bureau of Labor Statistic. Annual data for FDI in the United States for a 19-year period from 2000-2018 and inflation rate data of the same period of years were analyzed using the SPSS 26 software application. The data is believed to be valid and reliable considering the source.

In the study, quantitative method of analysis, the ordinary least squares (OLS) was employed as the econometric approach. The empirical analysis was used in assessing the relationship between FDI and the growth of the economy of United States. The variables for analysis are GDP as a measure of economic growth, inflows of FDI, and inflation rate. The variables were selected based on prior studies.

\subsection{Model Specification}

This research uses the multiple regression model with ordinary least square method to evaluate the potential significance of FDI on economic growth in the U.S. Multiple regression attempts to model the relationship between two or more explanatory variables and a response variable by fitting a linear equation to observed data.

$\widehat{\mathrm{GDP}}_{\mathrm{i}}=f(\mathrm{FDI}, \mathrm{INF}), \mathrm{GDP}=$ Gross Domestic Product (Dependent variable), FDI $=$ Foreign direct Investment, $\mathrm{INF}$ $=$ Inflation rate for United State (Independent variables). In statistical terms, the regression equation is presented as:

$\widehat{L G D P}_{i}=\hat{\beta}_{0}+\hat{\beta}_{1} L F D I+\hat{\beta}_{2} I N F_{i}+e_{i}$

where $\widehat{L G D P}_{i}$ - Gross Domestic Product (Log);

$\hat{\beta}_{0}$ - the intersection of the regression line with the $\mathrm{Y}$ axis, denoting the value of $\mathrm{Y}$, when the values of $\mathrm{X}$ are equal 0 ;

$\hat{\beta}_{1} L F D I-$ Foreign Direct Investment (Log) inflow in United States;

$\hat{\beta}_{2} I N F$ - Inflation rate of United States;

$e_{i}$ - error term.

$\mathrm{H}_{0}$ : Foreign direct investments do not have a positive significant influence on Gross Domestic Products. 
$\mathrm{H}_{1}$ : Foreign direct investments have a positive significant influence on Gross Domestic Products.

\subsection{Results and Findings}

\section{F-Test Finding}

The F- Test or Analysis of Variance (ANOVA) shows whether all independent variables in the model do contribute significantly to the dependent variable or not simultaneously. Here is the finding from SPSS 26 of F-test.

Table 1. Table of F-Test

\begin{tabular}{|l|l|l|l|l|l|}
\hline Model & Sum of Squares & Df & Mean Square & F & Sig. \\
\hline Regression & 0.787 & 2 & 0.393 & 342.014 & 0.000 \\
\hline Residual & 0.018 & 16 & 0.001 & & \\
\hline Total & 0.805 & 18 & & & \\
\hline
\end{tabular}

a. Dependent Variable: LGDP

b. Predictors: (Constant), INF, LFDI

Source: the secondary data is computed in SPSS 26

To know whether the model fit or not, if sig. $>0.05$ then the model is rejected but if sig. $<0.05$ then the model is accepted. From the table 1 above, it can be concluded that the model is accepted, and all independent variables show significant impact on dependent variable. Therefore, we reject null hypothesis $\left(\mathrm{H}_{0}\right)$.

\section{t-Test Finding}

T-test shows whether all independent variables in the model do contribute significantly to dependent variable partially. See the finding from SPSS 26 of t-test below.

Table 2. Table of t-Test

\begin{tabular}{|l|l|l|l|l|l|}
\hline Model & $\begin{array}{l}\text { Unstandardized } \\
\text { B }\end{array}$ & $\begin{array}{l}\text { Coefficients } \\
\text { Std. Error }\end{array}$ & $\begin{array}{l}\text { Standardized } \\
\text { Coefficient Beta }\end{array}$ & T & Sig \\
\hline 1 (Constant) & 2.254 & 0.030 & & 75.721 & 0.000 \\
\hline LFDI & 0.538 & 0.022 & 0.995 & 24.278 & 0.000 \\
\hline INF & 0.003 & 0.008 & 0.016 & 0.394 & 0.699 \\
\hline
\end{tabular}

Dependent Variable: LGDP

Source: the secondary data is computed in SPSS 26

The Table 2 explains the significance of each of the independent variable on the dependent variable. From the t-test table above, the independent variable, LFDI has a significance level of 0.05 , therefore, we fail to reject the alternative hypothesis, $\mathrm{H}_{1}$ and reject the $\mathrm{H}_{0}$. We conclude that foreign direct investments provide significant impact on the economic growth of United States while inflation rate does not.

The logarithm of foreign direct investment shows that an increase in the variable will lead to an increase in gross domestic product. For the years 2000 to 2018, a percent change in foreign direct investment by $1 \%$ on an average increased GDP by $53.80 \%$. The finding is consistent with the study of Bhatt (2014) that FDI is significant in the economic growth of a nation. The result of this study also aligns with the empirical findings of Tan \&Tang (2016) on the positive influence of FDI on economic growth. Similarly, the findings by Balasubramanyam et al. (1996), Borensztein et al (1998), Ram \& Zhang (2002) and Frenkel et al (2004) all established that FDI does contribute to economic growth.

Table 3. Table of $\mathrm{R}^{2}$ Finding

\begin{tabular}{|l|l|l|l|l|}
\hline Model & R & R Square & Adjusted R Square & Std. Error of the Estimate \\
\hline 1 & 0.989 & 0.977 & 0.974 & 0.03391 \\
\hline
\end{tabular}

Predictors: (Constant). LFDI, INF

Dependent Variable: LGDP

Source: the secondary data is computed in SPSS 26

The $\mathrm{R}$ square which determines the impact strength of independent variables on dependent variable in this study is $97.70 \%$. This means that $97.70 \%$ of GDP growth is influenced by the variables, FDI inflow and inflation rate, while $2.30 \%$ is influenced by other variables not included in the model. The adjusted $\mathrm{R}$ square is $97.40 \%$, that is, $97.40 \%$ of economic growth in the U.S is affected by foreign direct investment and inflation rate and the remaining $2.60 \%$ is affected by other variables out of the research model. The statistical result above indicates that changes in FDI correlate with shifts in GDP. As the rate of growth of the U.S. economy improves progressively, inflation rate was under control and the foreign direct investment in the United States increases steadily. In figure 2 , we see that gross domestic product increases as foreign direct investment increases for the years under consideration. 
Figure 2: GDP and FDI inflow for United States from 2000-2018

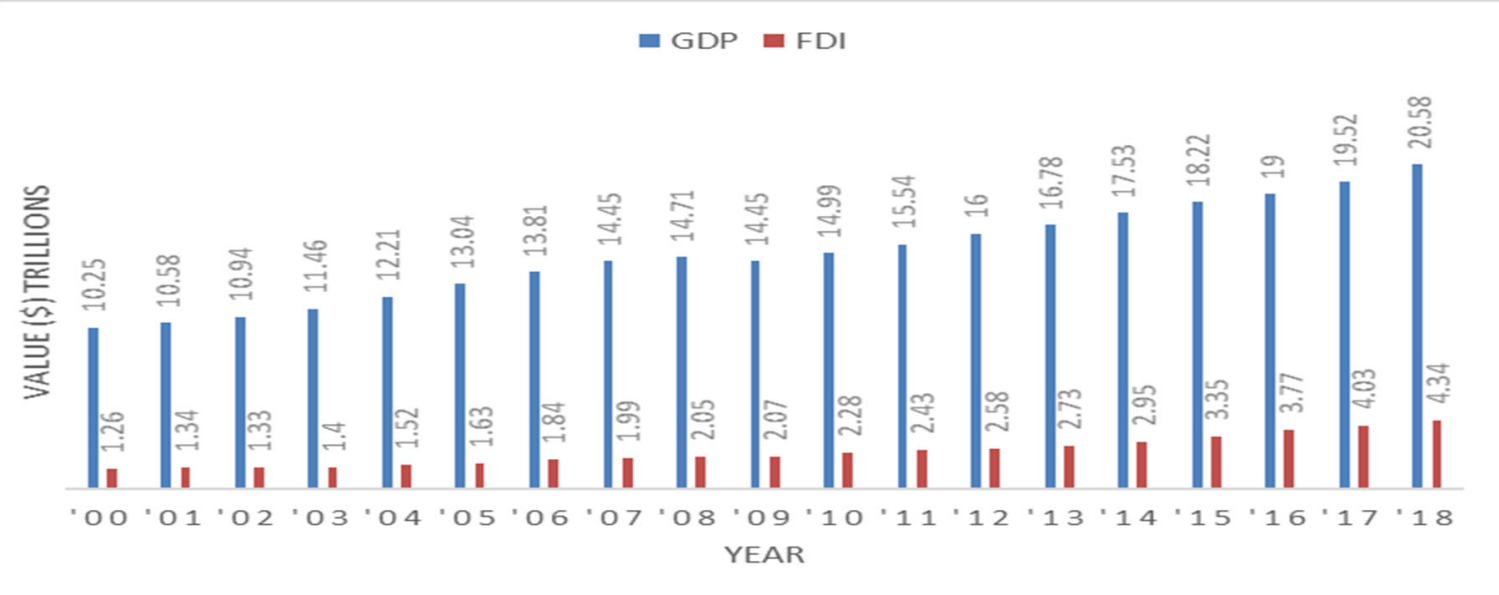

Source of Data: Bureau of Economic Analysis, 2020

\subsection{Conclusion}

The findings of the study have shown that FDI has a positive statistical significance to the economic growth of United States. The consistency in the flow of FDI to the country has indicated that foreign investors have confidence in the United States. International investors have assurance on the stability of the nation as well as the advanced technology it has among the developed economies. The country's strong institutional structure and political stability boost the confidence of foreign investors. Historical performance and location advantages have made the country to attract more FDI from other developed and emerging economies; this provides a significant influence on economic growth.

It has become imperative for developed and developing countries to attract foreign investment to enhance their economies because FDI has a low volatility and long-term commitment in the host economy. In addition to this, FDI benefits the host country with its significant impact on economic growth through technology transfer and employment effect. FDI drives innovation, brings new technologies to improve productivity, and connects American companies with the world. FDI creates additional activity at the local, regional, and national economic levels as many companies rely on other companies within their supply chains.

The United States will remain an attractive destination for foreign investment. However, policy makers need to consistently nurture and build upon the underlying strengths of the U.S. economy so that international investors will continue to invest in the country. The government of United States should continue to revamp investment and fiscal policies to attract new foreign investors, knowing their competitors are strategizing to lead the global economy. Moreover, they should leverage on activities like building new infrastructures, increasing the numbers of skilled labor, maintaining world-class research universities, and increasing the level of transparency in their regulatory bodies and institutional systems.

This research does not provide information on how institutional factors influence FDI inflow in the United States. It is therefore recommended that future researchers can investigate the impact of institutional factors on FDI inflow in the country. A thorough examination of FDI at the states' level in the United States may also be considered.

\section{References}

Adams, S. (2009) "Foreign Direct investment, domestic investment, and economic growth in Sub-Saharan Africa." Journal of Policy Modeling, 31: 939-949.

Arısoy, I. (2012). The Impact of Foreign Direct Investment on Total Factor Productivity and Economic Growth in Turkey. The Journal of Developing Areas, 46(1), 17

Asheghian, P. (2004). Determinants of economic growth in the United States: The role of foreign direct investment. The International Trade Journal, 18, 63-83.

Attari, M. I. J., Kamal, Y., \& Attaria, S. N. (2011). The Causal Link between Foreign Direct Investment (Fdi) and Economic Growth in Pakistan Economy. Journal of Commerce (22206043), 3(4), 61-68.

Balasubramanyam, V. N., Salisu, M. \& Sapsford D. (1996). Foreign direct investment and growth in EP and is countries. The Economic Journal, 106, 92-105.

Bende-Nabende, A., Ford, J. and Slater, J. (2001). "FDI, regional economic integration and endogenous growth: some evidence from Southeast Asia", Pacific Economic Review, 6 (3): 383-399.

Bhatt, P. R. (2014). Foreign direct investment in ASEAN countries 1990-2012. Revista Galega de Economía, 23 , $133-144$. 
Blomström, M. \& Kokko, A. (1998). "Multinational corporations and spillovers”, Journal of Economic Surveys, 12 (3): $247-277$.

Borensztein, E., De Gregorio, J., \& Lee, J. W. (1998). How does foreign direct investment affect economic growth? Journal of international Economics, 45(1), 115-135

Chappelow, J. (2019). Economic growth. https://www.investopedia.com/terms/e/economicgrowth.asp

Chowdhury, A. and Mavrotas, G. (2003), "FDI and growth: what causes what?", WIDER conference on "Sharing global prosperity", WIDER, Helsínquia, Setembro 1 to 18

Chowdhury, A. \& Mavrotas, G. (2003). FDI and Growth: What Causes What? The World Economy, 29 (1), 9-19.

De Mello, L.R. (1999). "Foreign direct investment - led growth: evidence from time series and panel data", Oxford Economic Papers, Vol. 51, pp. 133-15.

El-Wassal, K. (2012). Foreign Direct Investment and Economic Growth in the Arab Region: The Case of Knowledge Spillover Effects. International Journal of Economics and Finance, 37, (4), 79-100.

Figlio, D. N. \& Blonigen B. A. (1999). The effects of foreign direct investment on local communities. Journal of Urban Economics, 48, 338-363.

Fountas, S., Karanasos, M., \& Kim, J. (2006). "Inflation Uncertainty, Output Growth Uncertainty and Macroeconomic Performance”, Oxford Bulletin of Economics and Statistics Vol. 68(3), pp. 319-334.

Frenkel, M., Funke K., \& Stadtmann G. (2004). A panel analysis of bilateral FDI flows to emerging economies. Economic systems, 28(3), 281-300

Gillman, M. \& Kejak, M. (2005). "Inflation and Balanced-Path Growth with Alternative Payment Mechanisms", Economic Journal, Vol. 115(500), pp. 247-270.

Hong, E. \& Sun L. (2011). Foreign Direct Investment and Total Factor Productivity in China: A Spatial Dynamic Panel Analysis. Oxford Bulletin of Economics and Statistics, 73(6), 771-791.

Investment Analysis SelectUSA (2017). "High-Tech Industries the Role of FDI in Driving Innovation and Growth 2017”. https://www.selectusa.gov/servlet/servlet.FileDownload?file=015t0000000U1eE

Jackson, J. K. (2017). U.S. Direct Investment Abroad: Trends and Current Issues. Congressional Research Service, $1-15$.

Kasibhatla, K., Stewart, D. and Khojasteh, M. (2008), "The role of FDI in high medium, low medium and lowincome countries during 1970 - 2005: empirical tests and evidence", Journal of Business \& Economics Studies, 14 (2): $60-72$.

Kim, K., and Bang H. (2008). "The Impact of Foreign Direct Investment on Economic Growth: A Case Study of Ireland”, KIEP Working Paper 08-04, Seoul: Korea Institute of International Economic Policy.

Iacovoiu, V. B. (2015). Considerations about Foreign Direct Investments and Economic Development. Petroleum - Gas University of Ploiesti Bulletin, Technical Series, 67(4), 73-81

Lee, M. and Tcha, M. (2004). "The color of money: the effects of foreign direct investment on economic growth in transition economies", Review of World Economies, 140 (2): 211-229.

Lensink, R. and Morrissey, O (2006), "Foreign direct investment: flows, volatility and the impacton growth", Review of International Economics, 14 (3): 478 - 493.

Li, X., and Liu, X. (2005). "Foreign Direct Investment and Economic Growth: An Increasingly Endogenous Relationship", World Development 33(3), “393-407

Mencinger, J. (2003). “Does foreign direct investment always enhance economic growth?”, Kilkos, 56 (4): 491 508 .

Mody, A. and Wang, F. (1997), "Explaining industrial growth in coastal China: economic reforms and what else?", World Bank Economic Review, 11: 293 - 325.

Mohnen, P. (2001), "International R\&D spillovers and economic growth" in Information Technology, Productivity and Economic Growth. Ed. Matti Pohoja, Oxford University Press, Oxford.

Nair-Reichert, U., \& Weinhold, D. (2001). Causality tests for cross-country panels: A new look at FDI and economic growth in developing countries. Oxford Bulletin of Economics and Statistics, 63(2), 153-171.

Ntembe, A., \& Sengupta, S. (2016). The Contributions of Us Foreign Direct Investments to Economic Growth in Sub-Saharin Africa: Evidence from Panel Data. Journal of the Northeastern Association of Business, Economics \& Technology, 19(1), 55-71

President Barack Obama, 'Statement by the President on United States Commitment to Open Investment Policy' (Office of the Press Secretary, 20 June 2011)

Organization for Economic Co-operation and Development, OECD (2002). "Foreign direct investment for development: maximizing benefits, minimizing costs". OECD, Paris.

Oladipo, O. S. (2007). Foreign Direct Investment and Growth in Mexico: An empirical investigation. Proceedings of the Northeast Business \& Economics Association, 87-91

Pegkas, P. (2015). The impact of FDI on economic growth in Eurozone countries. The Journal of Economic Asymmetries, 12, 124-132.

Ram, R., \& Zhang, K. H. (2002). Foreign direct investment and economic growth: Evidence from cross-country 
data for the 1990s. Economic Development and Cultural Change, 51(1), 205215.

Rana, P.B., Dowling, J.M. Jr. (1988). “The Impact of Foreign Capital on Growth: Evidence from Asian Developing Countries", The Developing Economies, Volume 26, Issue 1, pp. 3-11

Roy, A. and Van der Berg, H. (2006), "Foreign direct investment and economic growth: a time-series approach", Global Economy Journal, 6 (1): 1 - 19.

Sajid Anwar \& Lan Phi Nguyen (2010) Foreign direct investment and economic growth in Vietnam, Asia Pacific Business Review, 16:1-2, 183-202.

Susilo, D. (2018). The Impact of Foreign Direct Investment on Economic Growth (a Causal Study in the United States). BISE: Jurnal Pendidikan Bisnis dan Ekonomi Vol. 4 No. 1.

Tan, B. W., \& Tang, C. F. (2016). Examining the causal linkages among domestic investment, FDI, trade, interest rate and economic growth in ASEAN-5 countries. International Journal of Economics and Financial Issues, $6,214-220$.

UNCTAD (2008). "Transnational Corporations and the Infrastructure Challenge, World Investment Report 2008." New York and Geneva, United Nations.

U.S. Department of Commerce, International Trade Administration. (2008). Assessing trends and policies of foreign direct investment in the United States [electronic resource]. Washington, D.C.: U.S. Dept. of Commerce, International Trade Administration, 2008.

Vogiatzoglou, K., \& Thi, N. P. N. (2016). Economic openness and economic growth: A cointegration analysis for ASEAN-5 countries. The European Journal of Applied Economics, 13, 10-20.

Wang, M., (2009). "Foreign Direct Investment and Economic Growth: The Growth Accounting Perspective." Economic Inquiry, 47(4): 701-710.

Wu, C. \& G. Burge. 2017. Competing for Foreign Direct Investment: The Case of Local Governments in China. Article first published online (March 2017) at Public Finance Review

https://www.statista.com/statistics/191077/inflation-rate-in-the-usa-since-1990/

https://www.statista.com/statistics/188105/annual-gdp-of-the-united-states-since-1990/

https://www.statista.com/statistics/188870/foreign-direct-investment-in-the-united-states-since-1990/

https://www.bea.gov/data/intl-trade-investment/new-foreign-direct-investment-united-states 